\title{
ASSOCIATION OF HUMAN PARVOVIRUS B19 INFECTION WITH DEVELOPMENT AND CLINICAL COURSE OF MYALGIC ENCEPHALOMYELITIS / CHRONIC FATIGUE SYNDROME
}

\author{
Santa Rasa-Dzelzkalēja ${ }^{1, \#, ~ S v e t l a n a ~ C ̌ a p e n k o ~}{ }^{1}$, Angelika Krūmiṇa ${ }^{2}$, Yung-Cheng Lin $^{3}$, \\ and Modra Murovska ${ }^{1}$

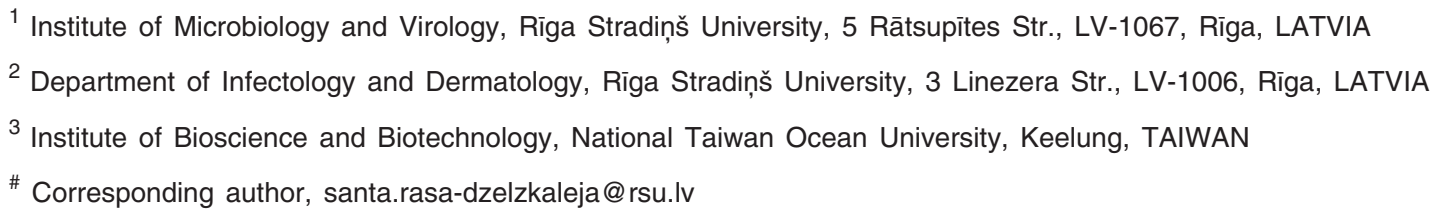

Contributed by Modra Murovska

Our aim was to estimate the presence of B19V infection markers, the level of cytokines and time period since the appearance of infection in association with ME/CFS clinical symptoms. In 200 ME/CFS patients and 104 control group individuals the presence of B19V-specific IgG/IgM class antibodies, B19V NS1 gene sequence, mRNA expression, viral load and level of cytokines were determined. B19V-specific IgG-antibodies were found in 70\% of ME/CFS patients and $67.4 \%$ of controls, IgM-antibodies in $8 \%$ of patients and in none of controls, B19V genomic sequences in $29 \%$ of patients and $3.8 \%$ of controls. $58.6 \%$ of positive patients had active and $41.4 \%$ had latent/persistent B19V infection. B19V NS1 gene expression was detected in $43 \%$ of patients. $B 19 \mathrm{~V}$ load varied from < 0.2 copies to median 38.2 copies/ $\mu g$ of DNA. According to the antibody pattern, $36 \%$ of patients had a recent, and $43 \%$ had sustained B19V infection. Patients with the B19V genomic sequence and NS1 specific antibodies significantly more often had lymphadenopathy and multi-joint pain. Onset of the symptoms corresponded to time of appearance of B19V infection. IL-10 and TNF- levels were higher in patients with elevated B19V load. B19V genome 1 was identified in Latvian ME/CFS patients. The results indicated that at least in some cases B19V infection plays an important role in ME/CFS development

Key words: human parvovirus B19, myalgic encephalomyelitis, chronic fatigue syndrome.

\section{INTRODUCTION}

Myalgic encephalomyelitis/chronic fatigue syndrome (ME/CFS) is a chronic, complex disease incorporating central nervous system and immune system disorders, cell energy metabolism and ion transport dysfunction, as well as cardiovascular abnormalities (Carruthers et al., 2011). $\mathrm{ME} / \mathrm{CFS}$ is characterised by severe chronic fatigue, accompanied by clinical symptoms like tender cervical or axillary lymph nodes, muscle pain, joint pain without swelling or redness, post-exertional malaise lasting more than 24 hours, impaired memory or concentration, headache of a new type, sore throat, and unrefreshing sleep (Fukuda et al., 1994).

Data on prevalence of ME/CFS varies depending on the used diagnostic criteria. ME/CFS has been reported for
$0.76 \%$ of clinically diagnosed and for $3.48 \%$ of the selfreported population (Johnston et al., 2013).

Infectious agents, such as hepatitis $\mathrm{C}$ virus, human immunodeficiency virus, coxsackie B, Epstein-Barr virus, human herpesvirus 6, human parvovirus B19 (B19V), borrelia, chlamydia and mycoplasma, have been associated with ME/CFS. However, involvement of a single specific infectious agent in ME/CFS development has not been established (Nicolson, 2002; Chapenko et al., 2006; Bansal et al., 2012; Chapenko et al., 2012).

B19V is an immunomodulating virus of the Parvoviridae family, Parvovirinae subfamily and Erythrovirus genus. It was first discovered in 1975 in blood serum of a healthy donor (Cossart et al., 1975). The B19V genome consists of 
linear single-stranded DNA, 5596 bases in length. The right side of the virus genome codes viral capsid proteins VP1 and VP2. B19V genome encodes also small proteins of 7.5 and $11 \mathrm{kDa}$ and non-structural protein NS1, which participates in production of infectious virus by regulating transcription and participating in replication (Ozawa et al., 1987; Momoeda et al., 1994; Luo and Qiu, 2015). The presence of B19V antibodies against NS1 indicate a severe and persistent B19V infection (von Poblotzki et al., 1995). The virus replicates mainly in primary target cells - erythroid progenitor cells in the bone marrow. However, B19V receptor (globoside), the antigenic determinant within the $\mathrm{P}$ blood group, is expressed not only on erythroblasts, but also on megakaryocytes, heart tissue, liver, lungs, kidneys, endothelium, aorta and gastro-intestinal smooth muscle tissues and synovium (Brown et al., 1993; Morey et al., 1993; Soderlund-Venermo et al., 2002). B19V can be detected also in non-erythroid cells and cells without $\mathrm{P}$ antigen (Munakata et al., 2006). $\alpha 5 \beta$ and Ku80 have been reported as B19V co-receptors (Luo and Qiu, 2015).

B19V has been frequently detected in children and young people, and therefore 60 to $80 \%$ of adults have antibodies against B19V (Cooling et al., 1995). B19V can cause infectious erythema, arthralgia, anaemia, aplastic crisis with reduced red blood cell lifespan and aplasia in immunocompromised patients, hydrops fetalis, various skin lesions, neutropenia, papular-purpuric gloves and socks syndrome, hepato-biliary diseases, cardiac syndromes, autoimmune and neurologic diseases (Kerr, 2000; Kerr, 2016).

After primary infection, B19V can remain in the body. Therefore, its association with different clinical manifestations has been studied, including encephalitis, encephalopathy, arthritis, autoimmune processes, fatigue and myalgic encephalomyelitis (Kerr and Tyrrell, 2003; Barah et al., 2014). B19V has been considered as one of possible trigger factors for ME/CFS (Appel et al., 2007).

The aim of this study was to determine the relationship between incidence of B19V infection markers, level of cytokines, the period of time from B19V infection onset in $\mathrm{ME} / \mathrm{CFS}$ patients and disease clinical course.

\section{MATERIALS AND METHODS}

Patients and controls. Two hundred patients from Latvia [130 (65\%) female and $70(35 \%)$ male, mean age $38 \pm 12$ ] with clinically diagnosed ME/CFS corresponding to criteria of 1994 Fukuda Centres for Disease Control and Prevention (CDC) and 104 apparently healthy individuals from Latvia were enrolled in this cross-sectional study. The study was conducted according to safety standards and the cohort was established with the approval of the Ethics Committee of Rīga Stradiňš University. All enrolled patients gave their informed consent prior to the study.

B19V specific antibody detection. Presence of B19V specific $\operatorname{IgM}$ and $\operatorname{IgG}$ class antibodies were detected in blood plasma using commercially available recomWell and recomLine Parvovirus B19 IgM and IgG kits (Mikrogen Diagnostik, Germany). Presence of specific antibodies against six antigens of $\mathrm{B} 19 \mathrm{~V}$ [ Vp-2p - main capsid antigen (conformation epitope); VP-N $-\mathrm{N}$-terminal half of the structure proteins VP-1 and VP-2; VP-1S - specific segment (differentiation to VP-2); VP-2r - main capsid antigen (linear epitope); VP-C - C-terminal half of the structure proteins VP-1 and VP-2; NS-1 - non-structure protein] was determined, and the obtained reaction patterns allowed to determine the period of time since appearance of B19V infection (Pfrepper et al., 2005). For example, an infection that had appeared a long time ago (months to years) often shows $\mathrm{IgG}$ reactivity against VP-2p and/or VP-N (usually with VP-1S). A recent infection (a few weeks to months) shows strong IgG reactivity against VP-C and presence of anti-VP-2r can be accompanied by anti-VP-2p, anti-VP-N and anti-VP-1S (Pfrepper et al., 2005). Presence of B19V specific NS1 antibodies and genomic sequence shows a persistent B19V infection (von Poblotzki et al., 1995).

Cytokine level detection. Level of cytokines was estimated in blood plasma according to manufacturers' protocols using enzyme-linked immunosorbent assays (ELISA): IL-4 Endogen Human ELISA kit (Pierce Biotechnology, Rockford, IL, USA), TNF- $\alpha$ - Biorbyt Human TNF $\alpha$ ELISA kit (Biorbyt, United Kingdom), IL-6 - eBioscience Human IL-6 Platinium ELISA, IL-10 - eBioscience Human IL-10 Platinium ELISA, and IL-12 (p70) eBioscience Human IL-12p70 Platinium ELISA (eBioscience Europe/International, Austria).

Nucleic acid preparation. DNA was extracted from whole peripheral blood and cell-free blood plasma by phenol-chloroform extraction method. RNA was extracted from peripheral blood mononuclear cells (PBMCs) using Tri Reagent (Applied Biosystems, USA). Quantity of extracted DNA and RNA was measured spectrophotometrically. Quality of RNA was determined in agarose gel and using complementary DNA (cDNA) synthesised with a RevertAid First Strand cDNA Synthesis Kit (Thermo Scientific, USA). To assure the quality of cDNA and DNA from peripheral blood, and to exclude possible contamination of plasma DNA by cellular debris DNA, $\beta$-globine polymerase chain reaction (PCR) was carried out. Potential cross-contamination during extraction and PCR was prevented by processing samples in separate rooms and including a negative control (DNA without the B19V genomic sequence) in each assay and a water control after every third sample.

Polymerase chain reactions. The B19V NS1 gene sequence was detected in DNA isolated from peripheral blood and cell free blood plasma by nested PCR (nPCR) according to Barah et al., 2001 protocol and primers (Barah et al., 2001). B19V NS1 gene expression was detected using reverse transcription PCR (RT-PCR) according to Ito et al., 2013 protocol and primers (Ito et al., 2013). Amplification products were analysed electrophoretically in agarose gel. Viral load was estimated by real-time PCR with a Parvovi- 
rus B19 Real-TM Quant kit (Sacace Biotechnologies, Italy) according to manufacturer's protocol.

Phylogenetic analysis. B19V positive PCR products were purified and sequenced with an ABI Prism 3100 Genetic Analyzer (Applied Biosystems, USA). Part of B19V NS1 genes was aligned by phylogenetic analysis (Tamura et al., 2013). To ensure the consistency of tree topologies, phylogenetic trees were reconstructed (Guindon et al., 2010; Tamura et al., 2013). The robustness of the phylogenetic trees was statistically evaluated by bootstrap analysis with 1000 replicates. The bootstrap value $75 \%$ was considered indicate a monophyletic group.

Data analysis. Statistical analysis was conducted with GraphPad Prism 6.0 (Chi-square, Fisher's exact and Mann-Whitney nonparametric tests). A value of $p<0.05$ was considered to be statistically significant.

\section{RESULTS}

B19V specific IgG class antibodies were found in $70 \%$ (140/200) of ME/CFS patients and 67.4\% (60/89) of apparently healthy individuals blood plasma samples $(p=$ 0.6803). None of the control group individuals had B19V specific IgM class antibodies while 8\% (16/200) of ME/CFS patients were IgM class antibody positive ( $p=$ $0.0018) ; 2.5 \%(5 / 200)$ had only IgM class antibodies and $5.5 \%(11 / 200)$ had both IgG and IgM class antibodies ( $p=$ 0.1695 and $p=0.0184$, respectively).

B19V genomic sequences in DNA isolated from whole blood were found in $29 \%(58 / 200)$ of patients and in $3.8 \%$ (4/104) of controls $(p<0.0001) .58 .6 \%$ (34/58) of B19V positive ME/CFS patients and $50 \%$ (2/4) of controls had viral genomic sequences in DNA isolated from cell-free blood plasma, while $41.4 \%(24 / 58)$ of patients and 50\% (2/4) controls had negative PCR in plasma DNA. B19V NS1 gene expression was detected in $43 \%(25 / 58)$ of ME/CFS patients. Considering that the virus genomic sequence was detected in DNA isolated from whole peripheral blood but not in DNA from cell free blood plasma, the virus genomic sequence was located in peripheral blood leukocytes (PBL). Therefore, the presence of B19V genomic sequence in DNA isolated from peripheral blood, and the DNA isolated from cell free blood plasma being negative, indicates a latent/persistent B19V infection in 12\% (24/200) of patients with ME/CFS and $1.9 \%(2 / 104)$ of apparently healthy individuals $(p=0.002)$. However, an active B19V infection (B19V genomic sequence detected in peripheral blood DNA as well as in DNA from cell-free blood plasma) was found in $17 \%(34 / 200)$ patients with ME/CFS and 1.9\% (2/104) of apparently healthy individuals $(p<0.0001)$ (Fig. 1).

RT-PCR B19V NS1 gene expression in PBMCs was detected in 25 of $58 \mathrm{ME} / \mathrm{CFS}$ patients who had B19V genomic sequences in whole blood DNA. Elevated viral load was detected in $20 \mathrm{ME} / \mathrm{CFS}$ patients (11 with viral genomic sequences in PBL and plasma DNA, 9 in PBL DNA only) and

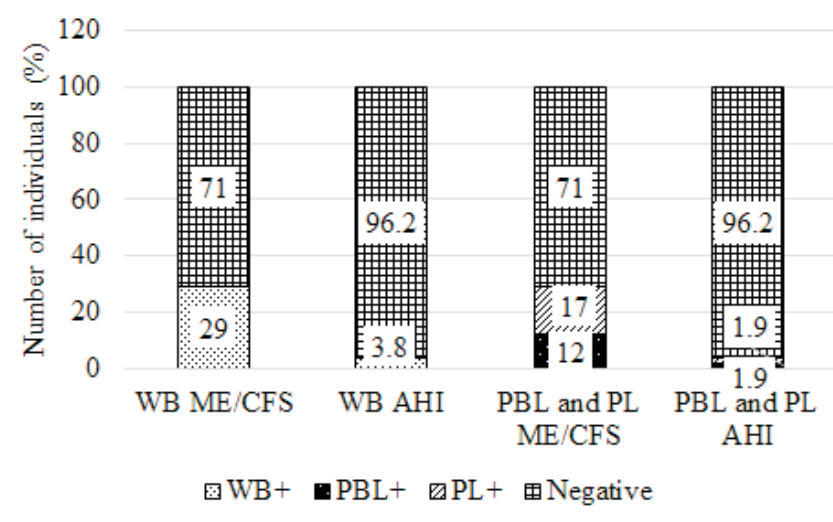

Fig. 1. Presence of B19V NS1 genomic sequence in DNA from peripheral blood cells and both peripheral blood and cell free blood plasma from patients with ME/CFS and apparently healthy individuals, WB - whole blood DNA; PBL - peripheral blood leukocyte DNA; PL - cell free plasma DNA; ME/CFS - myalgic encephalomyelitis/chronic fatigue syndrome; AHI - apparently healthy individuals.

in none of the apparently healthy individuals $(p=0.0003)$. The viral load in nine of 24 patients with a latent/persistent B19V infection (viral genomic sequences in PBL DNA) was [median (interquartile range - IQR)] 5.6 (27.4-0.8) copies/ $\mu \mathrm{g}$ DNA and in 15 patients was $<0.2$ copies/ $\mu \mathrm{g}$ DNA. In addition, in 11 of 34 patients with an active B19V infection (viral genomic sequences also in plasma DNA) the viral load was $38.2(217.5-17.7)$ copies/ $\mu$ g DNA and in 23 patients was $<0.2$ copies/ $\mu$ g DNA. All apparently healthy individuals with B19V infection had a viral load $<0.2$ copies/ $\mu$ g DNA (median viral load of a latent/persistent vs an active B19V infection $-p=0.0289$ ).

The B19V specific antibody reaction patterns of 75 randomly selected ME/CFS patients (39 with and 36 without the presence of $\mathrm{B} 19 \mathrm{~V}$ genomic sequence in DNA from whole blood) with a recomLine kit showed an acute B19V infection in one patient and a recent infection (weeks to months after B19V infection appearance) in $41 \%(16 / 39)$ of patients with $\mathrm{B} 19 \mathrm{~V}$ genomic sequence and in $30.6 \%(11 / 36)$ without the sequence $(p=0.4706)$. A sustained infection (months to years after B19V infection appearance) was observed in $56.4 \%$ (22/39) of patients with and $27.8 \%$ (10/36) and without the B19V genomic sequence in whole blood DNA ( $p=0.0191)$ (Fig. 2). $41.7 \%$ (15/36) of patients without the B19V genomic sequence did not have B19V specific antibodies, which indicates that they had never been infected with B19V. A severe course of ME/CFS was experienced by $18.5 \%(5 / 27)$ of patients with a recent B19V infection and $28.1 \%(9 / 32)$ with a sustained infection. $51.3 \%$ (20/39) of the patients with the B19V genomic sequence in DNA isolated from whole blood had B19V specific NS1 antibodies.

In ME/CFS patients without an elevated B19V load, the IL-6 level was $2.2(4.5-1.5) \mathrm{pg} / \mathrm{ml}$ [median (IQR)] and with elevated B19V load - 4.7 (14-2.7) $\mathrm{pg} / \mathrm{ml}(p=$ $0.1525)$. The TNF- $\alpha$ level in patients without and with elevated B19V load was $69.9(124.7-34.5)$ and 143 


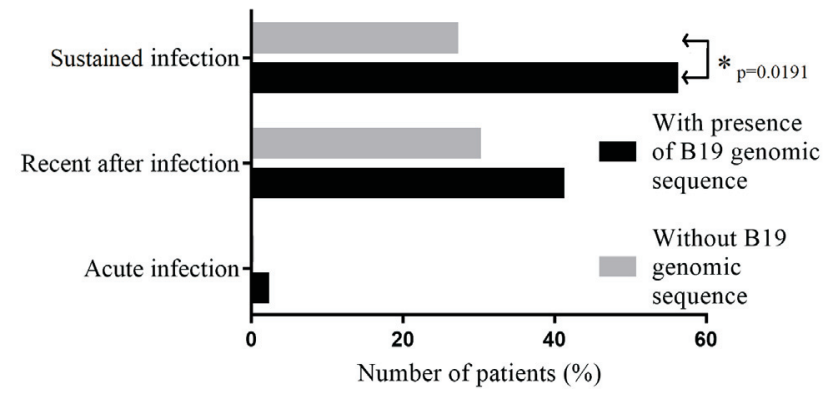

Fig. 2. Infection status after B19V infection onset in ME/CFS patients with and without presence of $\mathrm{B} 19 \mathrm{~V}$ genomic sequence in DNA from peripheral blood and/or blood plasma [* shows statistically significant result by Fisher's exact test $(p<0.05)]$.

(205.5-69.1) $\mathrm{pg} / \mathrm{ml}$, respectively $(p=0.0463)$. The IL-10 level in patients without an elevated B19V load was 11 (19.5-5) $\mathrm{pg} / \mathrm{ml}$ and with elevated B19V load - 20 (80-9.9) $\mathrm{pg} / \mathrm{ml}(p=0.0509)$. The IL-12 level in patients without and with elevated B19V load was $14.2(15.8-11.7)$ and 15.5
(18.6-10.2) pg/ml, respectively ( $p=0.4166$ ) (Fig. 3). The IL-4 level in all cases was $<2 \mathrm{pg} / \mathrm{ml}$.

Figure 4 shows the percentage of ME/CFS typical clinical symptoms in the observed patients with and without detectable NS1 antibodies in the presence of B19V genomic sequence in whole blood DNA. Of them, $55 \%$ of patients with and $21.1 \%$ without NS1 antibodies had multi-joint pain ( $p=$ 0.0294). Muscle pain was experienced by $65 \%$ and $42.1 \%$, while lymphadenopathy in $65 \%$ of patients with and $31.6 \%$ without NS1 antibodies, respectively $(p=0.1517$ and $p=$ $0.0369)$.

The onset of ME/CFS symptoms was determined six months up to three years before inclusion in the study. In $93.3 \%(70 / 75)$ of the cases onset of symptoms had occurred before $8.3 \pm 1.7$ months and in $6.7 \%(5 / 75)$ symptoms had started before $28.8 \pm 5.9$ months. In patients with a recent B19V infection, symptoms had started before $8.3 \pm 1.6$ months and with a sustained infection $-12.1 \pm 7.8$ months earlier (from them $25 \%$ - more than 12 months earlier).
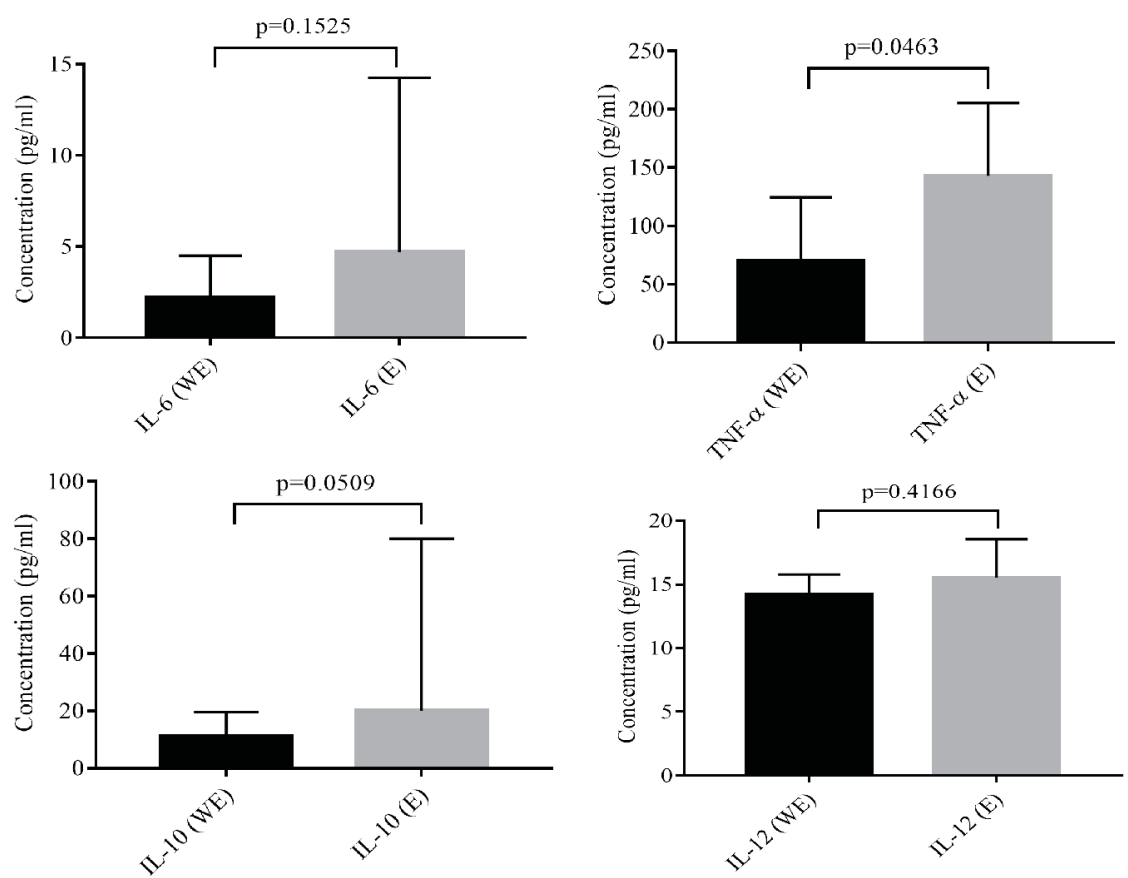

Fig. 3. Level of cytokines in ME/CFS patients with and without elevated B19V load, $p$ value was estimated using the Mann-Whitney nonparametric test [WE - without elevated B19V load, E - with elevated B19V load].

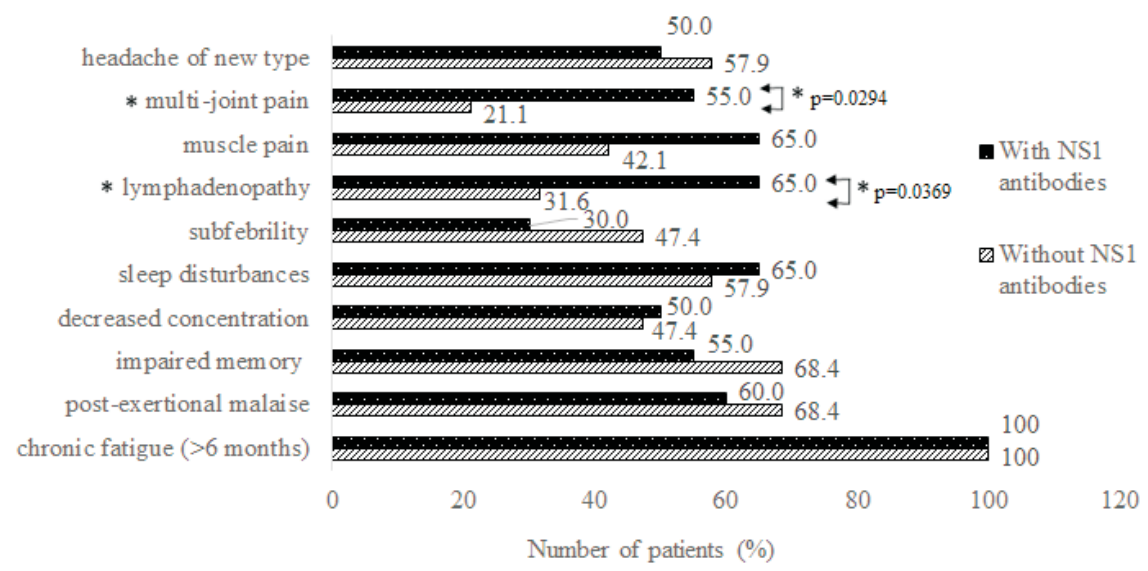

Fig. 4. Number of ME/CFS typical symptoms in patients with presence of B19V genomic sequence with and without B19V specific NS1 antibodies [* shows statistically significant result by the Chi-square test $(p<$ $0.05)]$. 
Although two B19V genotypes (genotype 1 and 2) were revealed in Latvia, the results of phylogenetic analysis of the B19V NS1 gene

(CAGGTTATGTGTATTAAAGACAATAA

AATTGTTAAATTGTTACTTTGTCAAAACTATGACCC CCTATTGGTGGGGCAGCATGTGTTAAAGTGGATTG ATAAAAAATGTGGCAAGAAAAATACACTGTGGTTT TATGGGCCGCCAAGTACAGGAAAAACAAACTTGG CAATGGCCATTGCTAAAAGTGTTCCAGTATATGGC ATGGTTAACTGGAATAATGAAAACTTTCCATTTAA TGATGTGGCAGGGAAAAGCTTGGTGGTCTGGGATG AAGGTATTATTAAGTCCACAATTGTAGAAGCTGCA AAAGCCATTTTAGGCGGGCAACCTACCAGGGTAGA TCAAAAAA

TGCGTGGAAGTGTAGCTGTGCCTGGAGTACCTGTG GTTATAACCAGC) showed genotype 1 circulation in patients with ME/CFS (Fig. 5). The majority of Latvian isolates (also from patients with diagnoses other than $\mathrm{ME} / \mathrm{CFS}$ ) were clustered with genotype 1 . Consistent tree topologies were observed with both of neighbour-joining and maximum likelihood methods. The gene diversity for genotype 1 was low $-0.3 \sim 1.1 \%$.

\section{DISCUSSION}

ME/CFS is a multifactorial disease accompanied by severe chronic fatigue without pathophysiological explanation, which reduced or loss of ability to work. There is no consensus on presence, form and the level of immune dysfunction in case of ME/CFS (Bansal et al., 2012). ME/CFS often commences with prolonged stress or virus infection, which is considered as one of possible ME/CFS causal agents due to the fact that most of patients report sudden start of illness with "flu-like" infection symptoms. Some viral infections can result in post-infectious fatigue and many patients with ME/CFS have immunological disturbances that could result from virus infection or be promoted by the infection. However, involvement of virus infection in aetiopathogenesis of ME/CFS remains ambiguous (Morinet and Corruble, 2012)

In this study, the frequency of B19V specific IgG class antibodies was similar in patients with ME/CFS (70\%) and apparently healthy individuals $(67.4 \%)(p=0.6803)$. While none of the apparently healthy individuals lacked IgM class antibodies, $8 \%$ of patients with ME/CFS had detectable IgM class antibodies $(p=0.0018)$. The obtained results in this study are in accordance with other researchers' findings of a lack of a significant difference in B19V IgG class antibody frequency between patients and a control group. Some researchers reported that the $\mathrm{B} 19 \mathrm{~V}$ seroprevalence in the population varies from 60 to $80 \%$ (Cooling et al., 1995), but others showed B19V specific IgG class antibodies in $74 \%$ and IgM class antibodies only in one patient with ME/CFS (Zhang et al., 2010). Kerr with colleagues analysed markers for B19V infection in 200 apparently healthy individuals and 200 patients with ME/CFS, and showed no difference in $\mathrm{B} 19 \mathrm{~V}$ seroprevalence between these two groups (antiB19V VP2 IgG class antibodies were detected in $75 \%$ and $78 \%$, respectively). Presence of anti-B19V VP2 IgM class antibodies was reported in four ME/CFS patients (Kerr et al., 2010), which is typical also for general population (Zhang et al., 2010). It is known that B19V seroprevalence increases with age - from $2 \%$ in children less than five

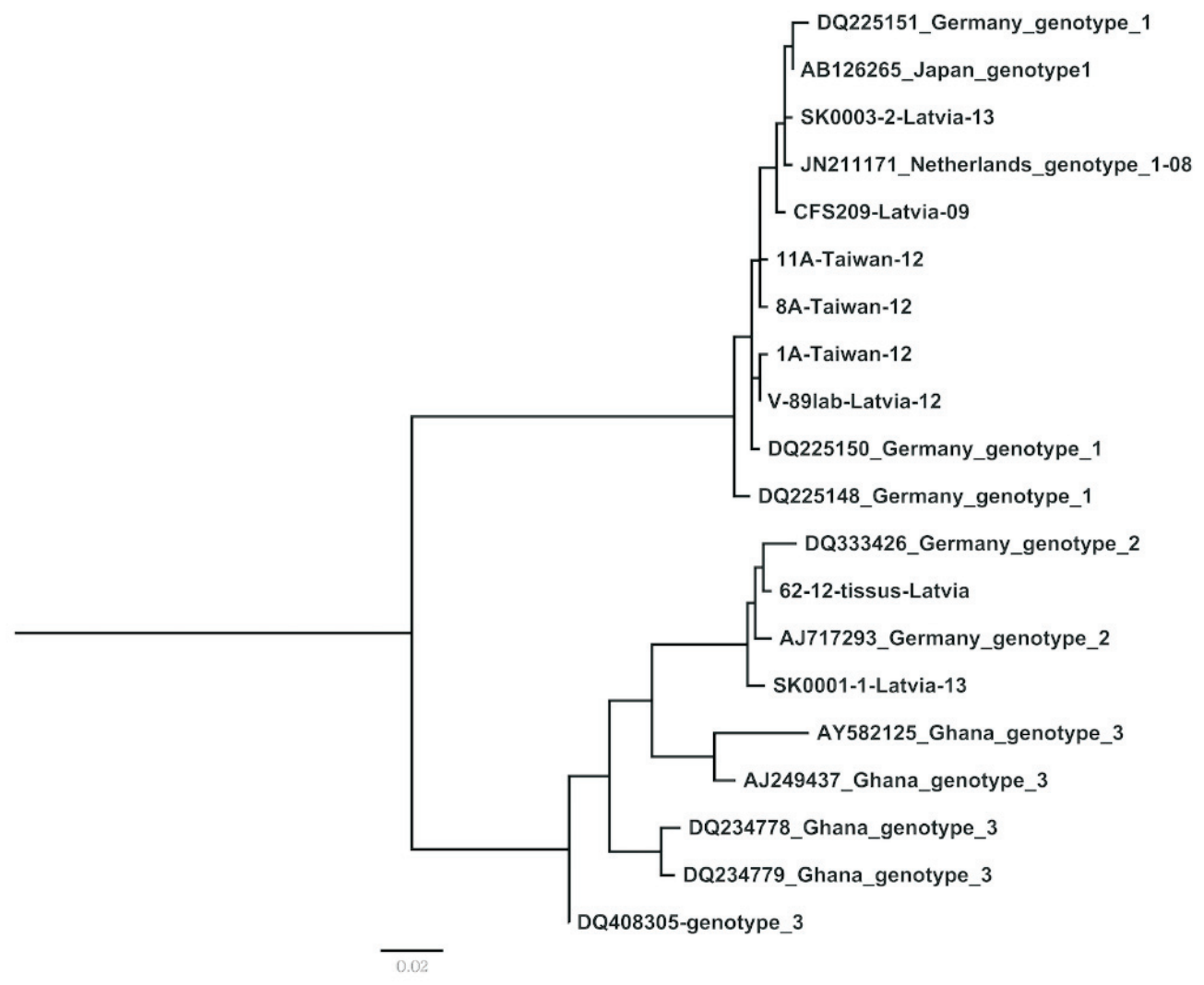

Fig. 5. Phylogenetic tree of human parvoviruses B19V based on the NS1 gene (396 bp). The phylogenetic tree was constructed using the maximum likelihood method. Only posterior probabilities values above $90 \%$ are shown. CFS209-Latvia-09 represents the isolate from a Latvian ME/CFS patient. 
years old up to $85 \%$ in older people (Servant-Delmas et al., 2010). Considering the mean age of our study cohort (38 \pm 12 years), the results are in accordance with the general population worldwide.

Data of our study showed the presence of B19V NS1 specific antibodies in $20 / 39(51.3 \%)$ of the ME/CFS patients, indicating the persistence of $\mathrm{B} 19 \mathrm{~V}$ infection. The results are similar to those reported by Kerr and co-authors, who detected IgG class antibodies against NS1 protein more frequently in patients with ME/CFS (41.5\%) than in healthy controls $(7 \%)$ and showed a relationship with a high level of expression of CFS-associated NHLH1 and GABPA genes. In that study anti-B19V NS1 IgM class antibodies were detected in three patients and one control group donor. Presence of B19V NS1 antibodies indicates a severe and persistent B19V infection, thereby in some patients, the immune system cannot sufficiently control the virus (von Poblotzki et al., 1995; Kerr et al., 2010).

In our study the frequency of B19V genomic sequence presence was higher in patients with ME/CFS (29\%) than in apparently healthy individuals $(3.8 \%)(p<0.0001)$. In case of a latent/persistent B19V infection (B19V genomic sequence only in DNA from PBL), a significant difference was found between patients $(12 \%)$ and apparently healthy individuals $(1.9 \%)(p=0.002)$. Moreover, an active B19V infection (B19V genomic sequence also in DNA from cell free blood plasma) was detected significantly more often in patients with ME/CFS (17\%) comparing with apparently healthy individuals $(1.9 \%)(p<0.0001)$. In addition, B19V NS1 gene expression occurred in patients with a persistent B19V infection, indicating virus replication in patient PBMCs. Other studies also reported the detection of B19V DNA, mRNA and protein in macrophages, T cells, B cells, follicular dendritic cells and monocytes (Takahashi et al., 1998), however B19V infection of the monocyte cell line U937 was shown to be abortive due to a lack of viral particle production (Munakata et al., 2006).

The majority of B19V infections worldwide are caused by B19V genotype 1 . Genotypes 2 and 3 have $10 \%$ nucleotide divergence from genotype 1. A higher frequency of genotype 2 has been observed among European individuals born before 1970s. However, genotype 3 circulates mainly in French, Brazilian, and Ghana individuals (Corcoran et al., 2010). Analysis of the B19V sequences from the National Centre for Biotechnology Information database obtained in several countries worldwide, this study for the first time showed B19V genotype 1 circulation in Latvian patients with ME/CFS.

The obtained results in this study coincide with findings of other researchers who showed that in a part of patients, $\mathrm{B} 19 \mathrm{~V}$ could be involved in ME/CFS development, based on detection of $\mathrm{B} 19 \mathrm{~V}$ infection markers in $40 \%$ of patients and almost $15 \%$ of apparently healthy individuals (Fremont et al., 2009). In our study, the frequency of elevated viral load was detected significantly more often in patients with ME/CFS compared to that in apparently healthy individuals $(p=0.0003)$. Furthermore, the viral load was higher in patients with an active B19V infection than in with a latent/persistent B19V infection $(p=0.0289)$. Published studies using real-time PCR also reported that the B19V genomic sequence occurred in patients with ME/CFS but not in control group blood donors (Kerr et al., 2010). However, some researchers reported no association of B19V infection with this disease, as B19V was not found in all ME/CFS cases (Sanders and Korf, 2008). It should be noted that in Brazil, the B19V genomic sequence was not detected in 141 Brazilian children with Exanthema subitum, by the age of four (Magalhaes Ide et al., 2011). Reviewing neurological aspects of $\mathrm{B} 19 \mathrm{~V}$ infection, nine reports found an association of ME/CFS with acute B19V infection, while two studies did not find such an association (Barah et al., 2014).

During a relatively recent or early infection phase, IgG reactivity against B19V VP1 linear epitopes, VP2 conformational and linear epitopes is present. After six months, IgG response to VP2 linear epitopes decreases; therefore, in the case of a sustained infection, antibodies against VP1 linear epitopes and VP2 conformational epitopes are present (Soderlund et al., 1995; Manaresi et al., 1999; Modrow and Dorsch, 2002; Pfrepper et al., 2005). Determination of B19V IgG and IgM class antibody patterns indicated an acute infection in one patient with ME/CFS. The antibody reaction pattern of a recent infection occurred more often in patients with the B19V genomic sequence $(41 \%)$ than without it $(30.6 \%)$, however without statistical significance ( $p=$ $0.4706)$. However, a sustained infection occurred significantly more often in patients with $(56.4 \%)$ the B19V genomic sequence in DNA from whole blood than without it $(27.8 \%)(p=0.0191)$. The presence of virus-specific IgG class antibodies in absence of the genomic sequence shows a past infection, while the presence of antibodies against B19V and B19V genomic sequence indicates a persistent B19V infection (Hemauer et al., 2000). Data shows that $\mathrm{B} 19 \mathrm{~V}$ infection can persist for years. A recent and sustained B19V infection was found in $36 \%$ and $43 \%$ of the patients, respectively. It corresponds to the onset of ME/CFS typical clinical symptoms (patients with a recent B19V infection before $8.3 \pm 1.6$ months and with a sustained infection $12.1 \pm 7.8$ months ago) indicating B19V infection as a trigger of the disease. Moreover, a severe clinical course of ME/CFS was experienced by more patients with a sustained B19V infection $(28.1 \%)$ than with a recent infection $(18.5 \%)$ showing disease progression.

The level of pro-inflammatory cytokines IL-6 and IL-12 was higher in patients with an elevated B19V load than without it. Moreover, TNF- $\alpha$ and IL-10 levels were significantly higher in patients with an elevated B19V load ( $p=$ 0.0463 and $p=0.0509$, respectively). The IL-4 level was not elevated in patients with ME/CFS. Viral infection induced a prolonged state of immune disbalance, accompanied by changes in the cytokine level, which might be the cause of ME/CFS clinical symptoms. The findings of our study are in concordance with previous reports indicating that Th1/Th2 cytokine response imbalance is reflected by 
increase of TNF- $\alpha$ and IL-10 levels, suggesting a persistent chronic infection (Couper et al., 2008; Brenu et al., 2011). Increased production of TNF- $\alpha$ and IL- 6 have also been reported in case of B19V infection (Kerr et al., 2001; Kerr and Tyrrell, 2003; Munakata et al., 2006).

According to $\mathrm{CDC}$ criteria, chronic fatigue is observed in all patients with ME/CFS. In this study patients with the B19V genomic sequence and antibodies to NS1 protein had significantly more frequently multi-joint pain $(55 \%)$ than patients with the B19V genomic sequence and without NS1 antibodies $(21.1 \%)(p=0.0294)$. Also, muscle pain and lymphadenopathy were more frequently observed in patients with $(65 \%$ and $65 \%)$ than without $(42.1 \%$ and $31.6 \%)$ presence of NS1 antibodies ( $p=0.1517$ and $p=0.0369$, respectively). Such B19V associated clinical manifestations as fatigue, lymphadenopathy, joint and muscle pain in patients with ME/CFS could be consequences of the virus infection. Since B19V can cause typical clinical symptoms of $\mathrm{ME} / \mathrm{CFS}$, some studies report that this virus is one of the trigger factors for at least part of ME/CFS patients (Matano et al., 2003; Appel et al., 2007; Fremont et al., 2009), which coincides with the results of our study.

$\mathrm{ME} / \mathrm{CFS}$ can be caused by various factors, and some viruses or other infectious agents may contribute to a subset for this disease, confirming the hypothesis of B19V as a trigger factor for ME/CFS (Kerr et al., 2010).

In our study, an active B19V infection was found significantly more frequently and with a higher viral load among patients with ME/CFS than apparently healthy individuals and a part of typical ME/CFS clinical symptoms were associated with $\mathrm{B} 19 \mathrm{~V}$ infection, indicating the importance of this infection in ME/CFS development and clinical course. Therefore, markers of B19V infection could be used as one of biomarkers in ME/CFS diagnostics.

\section{ACKNOWLEDGMENTS}

This study was funded in parts by the projects: Taiwan-Latvia-Lithuania Cooperation Project "Establishing of the Framework to Track Molecular Epidemiology of Parvoviruses and to Correlate Sequence Variability with Different Clinical Manifestations" No. 6.2.-25/2013/0039. RSU ZP 13/2013 "Association of fibromyalgia and myalgic encephalomyelitis/chronic fatigue syndrome with betaherpesviruses (HHV-6A, HHV-6B, HHV-7) and parvovirus B19V infection", "Support for doctoral study programs and research degrees $R S U$ "

(2009/0147/1DP/1.1.2.1.2/09/IPIA/VIAA/009), and BALTINFECT "Unlocking infectious diseases research potential at Riga Stradins University" (Grant agreement No. $316275)$ within the European Union $7^{\text {th }}$ Framework Programme.

\section{REFERENCES}

Appel, S., Chapman, J., Shoenfeld, Y. (2007). Infection and vaccination in chronic fatigue syndrome: Myth or reality? Autoimmunity, 40, 48-53.
Bansal, A. S., Bradley, A. S., Bishop, K. N., Kiani-Alikhan, S., Ford, B. (2012). Chronic fatigue syndrome, the immune system and viral infection. Brain Behav. Immun., 26, 24-31.

Barah, F., Vallely, P. J., Chiswick, M. L., Cleator, G. M., Kerr, J. R. (2001) Association of human parvovirus B19 infection with acute meningoencephalitis. Lancet, 358, 729-730.

Barah, F., Whiteside, S., Batista, S., Morris, J. (2014). Neurological aspects of human parvovirus B19 infection: A systematic review. Rev. Med. Virol., 24, 154-168.

Brenu, E. W., van Driel, M. L., Staines, D. R., Ashton, K. J., Ramos, S. B., Keane, J., Klimas, N. G., Marshall-Gradisnik, S. M. (2011). Immunological abnormalities as potential biomarkers in chronic fatigue syndrome/myalgic encephalomyelitis. J. Transl. Med., 9, 81 .

Brown, K. E., Anderson, S. M., Young, N. S. (1993). Erythrocyte P antigen: Cellular receptor for B19 parvovirus. Science, 262, 114-117.

Carruthers, B. M., van de Sande, M. I., De Meirleir, K. L., Klimas, N. G., Broderick, G., Mitchell, T., Staines, D., Powles, A. C., Speight, N., Vallings, R., Bateman, L., Baumgarten-Austrheim, B., Bell, D. S., Carlo-Stella, N., Chia, J., Darragh, A., Jo, D., Lewis, D., Light, A. R., Marshall-Gradisbik, S., Mena, I., Mikovits, J. A., Miwa, K., Murovska, M., Pall, M. L., Stevens, S. (2011). Myalgic encephalomyelitis: International Consensus Criteria. J. Intern. Med., 270, 327-338.

Chapenko, S., Krumina, A., Kozireva, S., Nora, Z., Sultanova, A., Viksna, L., Murovska, M. (2006). Activation of human herpesviruses 6 and 7 in patients with chronic fatigue syndrome. J. Clin. Virol., 37 Suppl 1, S47-51.

Chapenko, S., Krumina, A., Logina, I., Rasa, S., Chistjakovs, M., Sultanova, A., Viksna, L., Murovska, M. (2012). Association of active human herpesvirus-6, -7 and parvovirus b19 infection with clinical outcomes in patients with myalgic encephalomyelitis/chronic fatigue syndrome. $A d v$. Virol., 2012, 205085.

Cooling, L. L., Koerner, T. A., Naides, S. J. (1995). Multiple glycosphingolipids determine the tissue tropism of parvovirus B19. J. Infect. Dis., 172, 1198-1205.

Corcoran, C., Hardie, D., Yeats, J., Smuts, H. (2010). Genetic variants of human parvovirus B19 in South Africa: Circulation of three genotypes and identification of a novel subtype of genotype 1. J. Clin. Microbiol., 48, $137-142$.

Cossart, Y. E., Field, A. M., Cant, B., Widdows, D. (1975). Parvovirus-like particles in human sera. Lancet, 1, 72-73.

Couper, K. N., Blount, D. G., Riley, E. M. (2008). IL-10: The master regulator of immunity to infection. J. Immunol., 180, 5771-5777.

Fremont, M., Metzger, K., Rady, H., Hulstaert, J., De Meirleir, K. (2009) Detection of herpesviruses and parvovirus B19 in gastric and intestinal mucosa of chronic fatigue syndrome patients. In Vivo, 23, 209-213.

Fukuda, K., Straus, S. E., Hickie, I., Sharpe, M. C., Dobbins, J. G., Komaroff, A. (1994). The chronic fatigue syndrome: A comprehensive approach to its definition and study. International Chronic Fatigue Syndrome Study Group. Ann. Intern. Med., 121, 953-959.

Guindon, S., Dufayard, J. F., Lefort, V., Anisimova, M., Hordijk, W. Gascuel, O. (2010). New algorithms and methods to estimate maximum-likelihood phylogenies: Assessing the performance of PhyML 3.0. Syst. Biol., 59, 307-321.

Hemauer, A., Gigler, A., Searle, K., Beckenlehner, K., Raab, U., Broliden, K., Wolf, H., Enders, G., Modrow, S. (2000). Seroprevalence of parvovirus B19 NS1-specific IgG in B19-infected and uninfected individuals and in infected pregnant women. J. Med. Virol., 60, 48-55.

Ito, K., Shimizu, N., Watanabe, K., Saito, T., Yoshioka, Y., Sakane, E., Tsunemine, H., Akasaka, H., Kodaka, T., Takahashi, T. (2013). Analysis of viral infection by multiplex polymerase chain reaction assays in patients with liver dysfunction. Intern. Med., 52, 201-211. 
Johnston, S., Brenu, E. W., Staines, D., Marshall-Gradisnik, S. (2013). The prevalence of chronic fatigue syndrome/ myalgic encephalomyelitis: A meta-analysis. Clin. Epidemiol., 5, 105-110.

Kerr, J. R. (2000). Pathogenesis of human parvovirus B19 in rheumatic disease. Ann. Rheum. Dis., 59, 672-683.

Kerr, J. R. (2016). The role of parvovirus B19 in the pathogenesis of autoimmunity and autoimmune disease. J. Clin. Pathol., 69, 279-291.

Kerr, J. R., Barah, F., Mattey, D. L., Laing, I., Hopkins, S. J., Hutchinson, I. V., Tyrrell, D. A. (2001). Circulating tumour necrosis factor-alpha and interferon-gamma are detectable during acute and convalescent parvovirus B19 infection and are associated with prolonged and chronic fatigue. $J$. Gen. Virol., 82, 3011-3019.

Kerr, J. R., Gough, J., Richards, S. C., Main, J., Enlander, D., McCreary, M., Komaroff, A. L., Chia, J. K. (2010). Antibody to parvovirus B19 nonstructural protein is associated with chronic arthralgia in patients with chronic fatigue syndrome/myalgic encephalomyelitis. J. Gen. Virol., 91, 893-897.

Kerr, J. R., Tyrrell, D. A. (2003). Cytokines in parvovirus B19 infection as an aid to understanding chronic fatigue syndrome. Curr. Pain Headache Rep., 7, 333-341.

Luo, Y., Qiu, J. (2015). Human parvovirus B19: A mechanistic overview of infection and DNA replication. Future Virol., 10, 155-167.

Magalhaes Ide, M., Martins, R. V., Vianna, R. O., Moyses, N., Afonso, L. A., Oliveira, S. A., Cavalcanti, S. M. (2011). Detection of human herpesvirus 7 infection in young children presenting with exanthema subitum. Mem. Inst. Oswaldo Cruz, 106, 371-373.

Manaresi, E., Gallinella, G., Zerbini, M., Venturoli, S., Gentilomi, G., Musiani, M. (1999). IgG immune response to B19 parvovirus VP1 and VP2 linear epitopes by immunoblot assay. J. Med. Virol., 57, 174-178.

Matano, S., Kinoshita, H., Tanigawa, K., Terahata, S., Sugimoto, T. (2003). Acute parvovirus B19 infection mimicking chronic fatigue syndrome. Intern. Med., 42, 903-905.

Modrow, S., Dorsch, S. (2002). Antibody responses in parvovirus B19 infected patients. Pathol. Biol. (Paris), 50, 326-331.

Momoeda, M., Wong, S., Kawase, M., Young, N. S., Kajigaya, S. (1994). A putative nucleoside triphosphate-binding domain in the nonstructural protein of B19 parvovirus is required for cytotoxicity. J. Virol., 68, 8443-8446.

Morey, A. L., Ferguson, D. J., Fleming, K. A. (1993). Ultrastructural features of fetal erythroid precursors infected with parvovirus B19 in vitro: Evidence of cell death by apoptosis. J. Pathol., 169, 213-220.
Morinet, F., Corruble, E. (2012). Chronic fatigue syndrome and viral infections. In: Snell, C. R. (Ed.). An International Perspective on the Future of Research in Chronic Fatigue Syndrome. InTech, Croatia, pp. 1-12.

Munakata, Y., Kato, I., Saito, T., Kodera, T., Ishii, K. K., Sasaki, T. (2006). Human parvovirus B19 infection of monocytic cell line U937 and antibody-dependent enhancement. Virology, 345, 251-257.

Nicolson, G. L. (2002). Co-infections in fibromyalgia syndrome, chronic fatigue syndrome and other chronic illnesses. Fibromyalgia Frontiers, 10, 5-9; 27-28.

Ozawa, K., Ayub, J., Hao, Y. S., Kurtzman, G., Shimada, T., Young, N. (1987). Novel transcription map for the B19 (human) pathogenic parvovirus. J. Virol., 61, 2395-2406.

Pfrepper, K. I., Enders, M., Motz, M. (2005). Human parvovirus B19 serology and avidity using a combination of recombinant antigens enables a differentiated picture of the current state of infection. J. Vet. Med. B Infect. Dis. Vet. Public Health, 52, 362-365.

Sanders, P., Korf, J. (2008). Neuroaetiology of chronic fatigue syndrome: An overview. World J. Biol. Psychiatry, 9, 165-171.

Servant-Delmas, A., Lefrere, J. J., Morinet, F., Pillet, S. (2010). Advances in human B19 erythrovirus biology. J. Virol., 84, 9658-9665.

Soderlund-Venermo, M., Hokynar, K., Nieminen, J., Rautakorpi, H., Hedman, K. (2002). Persistence of human parvovirus B19 in human tissues. Pathol. Biol. (Paris), 50, 307-316.

Soderlund, M., Brown, C. S., Spaan, W. J., Hedman, L., Hedman, K. (1995). Epitope type-specific IgG responses to capsid proteins VP1 and VP2 of human parvovirus B19. J. Infect. Dis., 172, 1431-1436.

Takahashi, Y., Murai, C., Shibata, S., Munakata, Y., Ishii, T., Ishii, K. Saitoh, T., Sawai, T., Sugamura, K., Sasaki, T. (1998). Human parvovirus B19 as a causative agent for rheumatoid arthritis. Proc. Natl. Acad. Sci. USA, 95, 8227-8232.

Tamura, K., Stecher, G., Peterson, D., Filipski, A., Kumar, S. (2013). MEGA6: Molecular Evolutionary Genetics Analysis version 6.0. Mol. Biol. Evol., 30, 2725-2729.

von Poblotzki, A., Hemauer, A., Gigler, A., Puchhammer-Stockl, E., Heinz, F. X., Pont, J., Laczika, K., Wolf, H., Modrow, S. (1995). Antibodies to the nonstructural protein of parvovirus B19 in persistently infected patients: Implications for pathogenesis. J. Infect. Dis., 172, 1356-1359.

Zhang, L., Gough, J., Christmas, D., Mattey, D. L., Richards, S. C., Main, J., Enlander, D., Honeybourne, D., Ayres, J. G., Nutt, D. J., Kerr, J. R. (2010). Microbial infections in eight genomic subtypes of chronic fatigue syndrome/myalgic encephalomyelitis. J. Clin. Pathol., 63, 156-164.

\section{CILVĒKA PARVOVĪRUSA B19 INFEKCIJAS SAISTĪBA AR MIALG̣ISKĀ ENCEFALOMIELĪTA / HRONISKĀ NOGURUMA SINDROMA ATTĪSTİBU UN KLĪNISKO GAITU}

Pētījuma mērkis bija noteikt cilvēka parvovīrusa B19 (B19V) infekcijas markiieru klātbūtni, citokīnu līmeni un laiku no infekcija sākuma, saistībā ar ME/CFS klīniskajiem simptomiem. 200 ME/CFS pacientiem un 104 kontroles grupas indivīdiem noteica B19V-specifisko IgG/IgM klases antivielu un B19V NS1 gēna secību klātbūtni, mRNS ekspresiju, vīrusa slodzi un citokīnu līmeni. B19V-specifiskās IgG klases antivielas atrada $70 \%$ no ME/CFS pacientiem un 67,4\% no kontrolēm, IgM klases antivielas — $8 \%$ no pacientiem un nevienam no kontroles grupas, bet B19V genoma secības - 29\% no pacientiem un 3,8\% no kontrolēm. 58,6\% no pozitīvajiem pacientiem bija aktīva, bet 41,4\% - latenta/persistenta B19V infekcija. B19V NS1 gēna ekspresiju konstatēja 43\% no pacientiem. B19V slodze bija no < 0,2 līdz

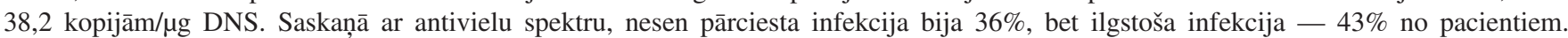
Limfadenopātija un locītavu sāpes būtiski biežāk bija pacientiem ar B19V genoma secību un NS1 antivielām. ME/CFS simptomu sākšanās laiks atbilst B19V infekcijas parādīšanās laikam. IL-10 un TNF- $\alpha$ līmenis bija augstāks pacientiem ar paaugstinātu B19V slodzi. ME/CFS pacientiem Latvijā atklāta B19V genoma 1 klātbūtne. Rezultāti liecina, ka vismaz daḷā gadījumu B19V infekcijai ir svarīga loma ME/CFS attīstībā. 